\title{
MENS LEGIS FRENTE A MENS LEGISLATORIS
}

\section{MENS LEGIS AGAINST MENS LEGISLATORIS}

José Carlos Navarro Muñoz: Arquitecto.

j.carlosnavarro@gmail.com

\section{CURRÍCULUM VITAE}

Arquitecto y analista político extremeño afincado en Mérida.

\section{RESUMEN}

Los tribunales de justicia, en su máxima interpretación de la ley, son los encargados de hacer coincidir la mente de la ley con la mente del legislador.

\section{PALABRAS CLAVE}

Tribunales de justicia - Ley - Legislador

\section{ABSTRACT}

The courts, at its best interpretation of the law, are responsible for matching the mind of the law with the mind of the legislator. 


\section{KEY WORDS}

Courts of Justice - Law - Legislator

\section{TEXTO}

Son precisamente los tribunales de justicia en su máxima interpretación de la ley, los encargados de hacer coincidir la mente de la ley con la mente del legislador. Puede resultarles complicado, cuando el legislador se aparta de los derechos y principios fundamentales, siendo su función constitucional última la de cumplir y hacer cumplir la ley emanada del poder legislativo. El presidente de la Sala Penal de la Audiencia Nacional, Javier Gómez Bermúdez, analiza las posibles formas de excarcelación de terroristas y sus dificultades basándose en lo anterior. Una forma es la de los indultos, que tiene la dificultad de no poder ser generalizada puesto que la Constitución lo prohíbe, por lo que habría que ir haciendo expedientes caso por caso. La segunda fórmula sería la del tercer grado penitenciario, que siendo un ejercicio administrativo, contempla igualmente la complicación de la individualidad de cada caso. Tercera y última, sería legislando para facilitar la excarcelación, con las dificultades que no se puede legislar para el tipo de origen criminal, por lo que se tendría que aplicar a todos los condenados independientemente que su causa sea el terrorismo. El problema para todas estas vías, sería que no podría aplicarse a los nuevos condenados. Bienvenido este razonamiento si es el porqué no se ha asesinado desde hace más de dos años.

Al ser más fuertes las reivindicaciones -y casi únicas, a excepción de los ataques por últimas resoluciones judiciales- respecto a la autodeterminación, no sería descabellado que la cuestión carcelaria fuera un tema ya abordado por los 
negociadores. Independiente el poder judicial del resto de poderes del Estado, hará siempre coincidir la mens legis con la mens legislatoris, siempre y cuando la coyunda no sea de imposible ejecución constitucional. Ahora bien, como la mens legis ante este espinoso asunto sólo es especulación, de las actuaciones de la mens legislatoris algo podrá interpretarse. Me refiero a que hace escasos días la vicepresidenta primera del Gobierno, visitó populistamente a los presos de una cárcel, prometiéndoles que realizarían una nueva forma de entender la prisión (facilitar la reinserción sin cárceles). Esa puede ser la clave de aplicación de la tercera vía del magistrado, encubierta en el populismo del buenísimo para todos los condenados, todos los terroristas podrían salir de la cárcel antes de 2010, como han anunciado recientemente desde la ilegalizada formación que los representa. 